\title{
HUBUNGAN BUDAYA KESELAMATAN PASIEN DAN INSIDEN KESELAMATAN PASIEN DI RUMAH SAKIT
}

Dewi Meylinta Sembiring Dewimeylinta7@ gmail.com

\section{LATAR BELAKANG}

Keselamatan pasien adalah prinsip dasar dalam pelayanan kesehatan. Menurut Depkes RI (2008) Keselamatan pasien (patient safety) rumah sakit adalah suatu sistem dimana rumah sakit membuat asuhan pasien lebih aman. Sistem tersebut meliputi: assessmen risiko, identifikasi dan pengelolaan hal yang berhubungan dengan risiko pasien, pelaporan dan analisis insiden, kemampuan belajar dari insiden dan tindaklanjutnya serta implementasi solusi untuk meminimalkan timbulnya risiko. Sistem tersebut diharapkan dapat mencegah terjadinya cedera yang disebabkan oleh kesalahan akibat melaksanakan suatu tindakan atau tidak melakukan tindakan yang seharusnya dilakukan. Keselamatan pasien dalam pelayanan kesehatan mendapatkan banyak perhatian sejak Institute of Medicine (IOM) pada tahun 2000 menerbitkan laporan yang berjudul “To Err is Human : Building a Safer Health System” yang mengemukakan Angka Kematian Akibat KTD pada pasien rawat inap di seluruh Amerika berjumlah 44.00098.000 orang pertahun. Dengan menggunakan estimasi yang lebih rendah, lebih banyak orang mati akibat kesalahan medis dalam setahun dibandingkan kecelakaan jalan raya, kanker payudara, atau AIDS.

Dalam Permenkes RI No. 1691/ MENKES/ PER/ VIII/ 2011 tentang Keselamatan Pasien Rumah Sakit, dikatakan Insiden keselamatan pasien yang selanjutnya disebut insiden adalah setiap kejadian yang tidak disengaja dan kondisi yang mengakibatkan atau berpotensi mengakibatkan cedera yang dapat dicegah pada pasien, terdiri dari Kejadian Tidak Diharapkan (KTD), Kejadian Nyaris Cedera (KNC), Kejadian Tidak Cedera (KTC) dan Kejadian Potensial Cedera (KPC). Salah satu tujuan keselamatan pasien yaitu menurunnya KTD yang merupakan bagian dari insiden keselamatan pasien. Untuk mencapai tujuan tersebut, maka disusunlah Sasaran Keselamatan pasien yang bertujuan mendorong perbaikan spesifik dalam keselamatan pasien. Sasaran menyoroti bagian-bagian yang bermasalah dalam pelayanan kesehatan dan 
menjelaskan bukti serta solusi dari konsensus berbasis bukti dan keahlian atas permasalahan yang ada. Penyusunan sasaran ini mengacu kepada Nine Life-Saving Patient Safety Solutions dari WHO Patient Safety (2007) yang digunakan juga oleh Komite Keselamatan Pasien Rumah Sakit PERSI (KKPRS PERSI), dan dari Joint Commission International (JCI).

Oleh karena itu, jika rumah sakit ingin menurunkan kejadian insiden keselamatan pasien maka rumah sakit harus menerapkan budaya keselamatan pasien. Sampai saat ini, banyak negara telah memulai penelitian budaya keselamatan pasien, baik Negara maju maupun Negara berkembang seperti Indonesia. Penelitian tentang budaya keselamatan pasien telah berkembang dalam beberapa tahun terakhir. Namun, masih kurang evaluasi objektif dan kuantitatif dari kualitas penelitian-penelitian tersebut. Tujuan dari tulisan ini adalah untuk mengetahui penerapan budaya keselamatan pasien terkait dengan insiden keselamatan pasien dengan berbasis bukti (Evidence Based)

\section{METODE}

Metode yang digunakan adalah metode kualitatif dan metode literature review, yaitu dengan mengumpulkan data, membaca, mengkaji dan menganalisis data tersebut dari berbagai sumber seperti buku teks, e-book,jurnal,buku referensi yang berhubungan dengan tema yaitu budaya dalam lingkup kerja perawat dalam peningkatan keselamatan. Kata kunci yang dimasukkan adalah kata kunci yang relevan dengan materi yaitu "Patient Safety Culture", "Patient Safety Incident'. Literature yang digunakan adalah sebanyak 12 dari berbagai sumber dengan ketentuan tahun terbit terakhir adalah tahun 2012 atau paling lama diterbitkan 8 tahun terakhir.

\section{HASIL}

Menurut The Health Foudation, 2011, budaya keselamatan berkaitan dengan sejauh mana organisasi memprioritaskan dan mendukung peningkatan keselamatan dengan aman. Organisasi dengan budaya keselamatan positif memiliki komunikasi atas dasar saling percaya, persepsi bersama tentang pentingnya keselamatan, keyakinan pada efektivitas langkah-langkah pencegahan, dan dukungan bagi tenaga kerja. Keselamatan (safety) telah menjadi isu global termasuk juga untuk rumah sakit. Oleh karena itu, keselamatan pasien merupakan prioritas utama untuk dilaksanakan dan hal tersebut terkait dengan terjadinya Insiden Keselamatan Pasien (IKP) di rumah sakit. Menurut Depkes 
RI (2008) dalam Panduan Nasional Keselamatan Pasien Rumah Sakit, langkah pertama program keselamatan pasien di rumah sakit adalah membangun budaya keselamatan pasien atau menumbuhkan kesadaran pada seluruh karyawan akan pentingnya nilai keselamatan di rumah sakit. Jadi, Untuk meningkatkan mutu pelayanan keselamatan pasien di tingkat unit maka harus dilakukan upaya perubahan budaya keselamatan pasien di seluruh unit Rumah Sakit.

Menurut Carthey \& Clarke (2010) dalam buku "Implementing Human Factors in Healthcare 'how to' Guide" bahwa organisasi kesehatan akan memiliki budaya keselamatan pasien yang positif, jika memiliki dimensi budaya sebagai berikut:

- Budaya keterbukaan (open culture). Budaya ini menggambarkan semua staf RS merasa nyaman berdiskusi tentang insiden yang terjadi ataupun topik tentang keselamatan pasien dengan teman satu tim ataupun dengan manajernya. Staf merasa yakin bahwa fokus utama adalah keterbukaan sebagai media pembelajaran dan bukan untuk mencari kesalahan ataupun menghukum. Komunikasi terbuka dapat juga diwujudkan pada saat serah terima pasien, briefing staff maupun morning report.

- Budaya keadilan (just culture). Hal tersebut membawa atmosfer "trust" sehingga anggota bersedia dan memilki motivasi untuk memberikan data dan informasi serta melibatkan pasien dan keluarganya secara adil dalam setiap pengambilan keputusan terapi. Perawat dan pasien diperlakukan secara adil saat terjadi insiden dan tidak berfokus untuk mencari kesalahan individu tetapi lebih mempelajari secara sistem yang mengakibatkan terjadinya kesalahan. Lingkungan terbuka dan adil akan membantu staf membuat pelaporan secara jujur mengenai kejadian yang terjadi dan menjadikan insiden sebagai pelajaran dalam upaya meningkatkan keselamatan pasien.

- Budaya pelaporan (reporting culture). Budaya dimana staf siap untuk melaporkan insiden atau near miss, sehingga dapat dinilai jenis error dan dapat diketahui kesalahan yang biasa dilakukan oleh staf serta dapat diambil tindakan sebagai bahan pembelajaran organisasi. Organisasi belajar dari pengalaman sebelumnya dan mempunyai kemampuan untuk mengidentifikasi faktor risiko terjadinya insiden sehingga dapat mengurangi atau mencegah insiden yang akan terjadi.

- Budaya belajar (learning culture). Setiap lini dari organisasi baik sharp end (yang bersentuhan langsung dengan pelayanan) maupun blunt end (manajemen) menggunakan 
insiden yang terjadi sebagai proses belajar. Organisasi berkomitmen untuk mempelajari insiden yang telah terjadi, mengkomunikasikan kepada staf dan senantiasa mengingatkan staf.

- Budaya informasi (informed culture). Organisasi mampu belajar dari pengalaman masa lalu sehingga memiliki kemampuan untuk mengidentifikasi dan menghindari insiden yang akan terjadi karena telah belajar dan terinformasi dengan jelas dari insiden yang sudah pernah terjadi, misalnya dari pelaporan kejadian dan investigasi.

\section{PEMBAHASAN}

Untuk meningkatkan mutu pelayanan keselamatan pasien di tingkat unit maka harus dilakukan upaya perubahan budaya keselamatan pasien di seluruh unit Rumah Sakit.

\section{a. Budaya Keselamatan Pasien}

Permintaan publik untuk perawatan yang lebih aman telah melambungkan usaha industri kesehatan untuk memahami hubungan antara keselamatan pasien dan kinerja rumah sakit. Penelitian Brown \& Wolosin (2013) mencoba mengeksplorasi hubungan antara persepsi staf terhadap budaya keselamatan dan langkah-langkah yang sedang berlangsung di rumah sakit berdasarkan struktur unit keperawatan, proses perawatan, dan resiko yang merugikan pasien. Hubungan antara tindakan keperawatan, kinerja rumah sakit dan budaya keselamatan dieksplorasi di 9 rumah sakit California dan 37 unit keperawatan. Persepsi budaya keselamatan diukur 6 bulan sebelum pengumpulan metrik keperawatan dan hubungan antara kedua data yang dieksplorasi menggunakan hubungan korelasional dan analisis regresi. Hubungan signifikan yang ditemukan adalah langkah-langkah proses untuk pencegahan jatuh. Beberapa asosiasi diidentifikasi dari budaya keselamatan dan struktur pemberian perawatan, seperti campuran keterampilan, pergantian staf, dan intensitas beban kerja menunjukkan hubungan yang signifikan dengan budaya keselamatan. Budaya keselamatan merupakan faktor penting untuk memahami upaya untuk memajukan perawatan pasien yang aman. Hasil ini memberikan implikasi kualitas pelayanan untuk kepemimpinan rumah sakit. Ketika para pemimpin memprioritaskan budaya keselamatan, resiko terhadap pasien mungkin telah diperbaiki dengan pergantian staf dan peningkatan produktivitas. Hal ini dapat dijadikan investasi dalam sistem keselamatan pasien untuk memberikan perawatan andal dan aman (Brown \& Wolosin, 2013) 
Untuk meningkatkan budaya keselamatan pasien, kesadaran perawat tentang pentingnya keselamatan pasien juga perlu ditingkatkan. Penelitian yang dilakukan oleh Kim dkk (2013) yang bertujuan untuk mengidentifikasi faktor- faktor yang mempengaruhi persepsi pentingnya dan praktek manajemen keselamatan pasien antara karyawan rumah sakit di Korea. Penelitian ini dilakukan dengan menggunakan desain deskriptif dan laporan kuesioner. 280 karyawan direkrut dari 3 rumah sakit menggunakan metode convenience sampling. Hasil penelitian ini menunjukkan bahwa faktor yang mempengaruhi persepsi pentingnya manajemen keselamatan pasien adalah apakah karyawan rumah sakit kontak dengan pasien saat bertugas, jam kerja mingguan, pendidikan manajemen keselamatan pasien, dan sistem konstruksi manajemen keselamatan pasien. Faktor yang mempengaruhi praktek manajemen keselamatan pasien adalah beban kerja, dan sistem konstruksi manajemen keselamatan pasien Hasil ini menunjukkan kebutuhan untuk mengembangkan strategi untuk meningkatkan persepsi pentingnya konstruksi dan praktek konstruksi di antara semua karyawan rumah sakit (Kim, Park, Park, Yoo, \& Choi, 2013)

Budaya keselamatan pasien merupakan faktor penting dalam upaya untuk mengurangi resiko yang merugikan di rumah sakit dan meningkatkan keselamatan pasien. Penelitian yang dilakukan Wang dkk (2014) ini bertujuan untuk mendeskripsikan persepsi perawat tentang budaya keselamatan pasien dan frekuensi resiko yang merugikan, dan menguji hubungan antara keduanya. Penelitian ini merupakan studi deskriptif korelasi, dimana penelti memilih 28 unit departemen rawat inap di 3 rumah sakit umum dari 5 kabupaten di Guangzhou, Cina, dan mensurvei 463 perawat. Survei Budaya Keselamatan Pasien digunakan untuk mengukur persepsi perawat tentang budaya keselamatan pasien, dan frekuensi resiko yang merugikan sering terjadi di rumah sakit yang diperkirakan oleh perawat. Hasil respon Budaya Keselamatan Pasien bervariasi dari $23,6 \%$ menjadi $89,7 \%$. Ada 47,8-75,6\% perawat yang memperkirakan bahwa peristiwa yang merugikan telah terjadi dalam satu tahun terakhir. Setelah mengendalikan semua factor, secara signifikan terkait untuk menurunkan terjadinya ulkus tekanan $(\mathrm{OR}=0,249)$, pengekangan fisik berkepanjangan ( $O R=0,406)$, dan keluhan $(\mathrm{OR}=0,369)$; secara signifikan terkait untuk menurunkan terjadinya kesalahan pengobatan $(\mathrm{OR}=0,699)$ dan ulkus 
tekanan $(\mathrm{OR}=0,639)$. Hasil tersebut menegaskan bahwa peningkatan budaya keselamatan pasien terkait dengan penurunan dalam terjadinya resiko yang merugikan (Wang, et al., 2014)

Budaya keselamatan pasien merupakan indikator kualitas penting dalam pelayanan kesehatan dan telah dikaitkan dengan hasil pasien yang diperoleh pasien di rumah sakit. Penelitian yang dilakukan oleh Hawkins \& Flynn (2015) yang bertujuan untuk menguji hubungan antara budaya keselamatan pasien dan kejadian merugikan pasien yang dilaporkan perawat dalam fasilitas rawat jalan hemodialisis. Metode penelitian ini adalah korelasional, menggunakan desain survei cross-sectional. Sampel analitik terdiri dari 422 perawat yang bekerja di fasilitas dialisis rawat jalan di Amerika Serikat. Hasil penelitian menunjukkan semua hubungan antara item budaya keselamatan pasien dan kejadian yang merugikan pasien berada di arah yang diharapkan. Hasil temuan dari analisis ini menunjukkan bahwa budaya keselamatan pasien yang positif merupakan variabel penting bagi hasil pasien yang optimal dalam pengaturan rawat jalan (Hawkins \& Flynn, 2015)

\section{b. Insiden Keselamatan Pasien}

Penelitian yang dilakukan oleh Yilmaz dan Goris (2014) pada 316 perawat yang bekerja di Intensive Care Unit (ICU) di Praktik Kesehatan dan Pusat Penelitian Universitas Erciyes dan Rumah Sakit Pendidikan Kayseri Turki dengan pendekatan survei deskriptif. Data dikumpulkan dengan menggunakan kuesioner Hospital Survey On Patient Safety Culture (HSOPSC) yang dikembangkan Agency for Healthcare Research and Quality (AHRQ). Hasil penelitian menemukan bahwa $13.6 \%$ perawat yang bekerja di ICU menghadapi potensi ancaman terhadap insiden keselamatan pasien, dimana $48.8 \%$ dari insiden tersebut adalah jatuh dan sebagian besar perawat yaitu $88 \%$ tidak pernah mendokumentasikan insiden tersebut. Oleh karena itu kesadaran perawat tentang keselamatan pasien harus ditingkatkan dan pengetahuan yang terkait harus terus di Update dengan sering memberikan pelatihan kepada perawat. (Yilmaz \& Goris, 2015)

Penelitian yang dilakukan oleh Agung Permadhi (2013) pada 133 tenaga perawat yang bekerja di Instalasi Rawat Inap RSD dr. Soebandi Jember, Jawa Timur dengan metode pengambilan data menggunakan kuesioner yang 
dimodifikasi dari Agency for Healthcare Research and Quality (AHRQ) tahun 2008 yang berjudul Hospital Survei On Patient Safety Culture (HSOPSC). Hasil penelitian menunjukkan bahwa tingkat budaya keselamatan pasien dalam pelayanan keperawatan di Instalasi Rawat Inap RSD dr. Soebandi Jember tahun 2013 termasuk dalam kategori baik (54,0\%). Namun, dari indikator budaya pelaporan dan respon tidak menghukum terhadap kesalahan menunjukkan hasil yang cukup. Sementara itu, tingkat insiden keselamatan pasien di Instalasi Rawat Inap RSD dr. Soebandi Jember tahun 2013 termasuk dalam kategori sering $(71,1 \%)$ yang artinya sebagian besar responden menilai bahwa frekuensi kejadian insiden keselamatan pasien dapat terjadi beberapa kali dalam waktu satu tahun. Oleh karena itu, dengan adanya peningkatan budaya pelaporan dan respon tidak menghukum terhadap kesalahan misalnya dengan melakukan evaluasi pada sitem pelaporan agar bisa diketahui penyebabnya. Selain itu, perlu adanya tindak lanjut bagaimana caranya untuk menurunkan angka kejadian insiden misalnya dengan mencari akar permasalahan agar dapat ditemukan atau didesain sistem yang baru sehingga tidak terjadi insiden serupa serta adanya umpan balik kepada unit pelapor agar mereka mengetahui sebab terjadinya insiden (Permadhi, 2013)

Kedua penelitian di atas menunjukkan bahwa insiden keselamatan pasien di rumah sakit masih sering terjadi, namun pelaporan insiden tersebut masih kurang dilakukan. Penelitan yang dilakukan Kroening, dkk (2015) yang dilator belakangi karena pasien tetap menjadi sumber daya kurang dimanfaatkan dalam upaya untuk meningkatkan kualitas dan keselamatan dalam perawatan kesehatan, meskipun ada bukti bahwa mereka dapat memberikan wawasan penting tentang perawatan yang mereka terima. Penelitian ini bertujuan untuk menentukan apakah insiden keselamatan pasien yang diprediksi dari keluhan sebelumnya, memungkinkan keluhan yang akan digunakan untuk mencegah insiden keselamatan pasien berikutnya. Pengumpulan data dilakukan dengan mengumpulkan keluhan yang diterima dari November 2011 sampai Juni 2012 dan memeriksa laporan kejadian Insiden keselamatan pasien dari April sampai September 2012. Keluhan dan Insiden keselamatan pasien dikategorikan menurut lokasi. Data dianalisis untuk mencari korelasi antara jumlah keluhan dan Insiden keselamatan pasien di daerah tertentu. Sebuah analisis kualitatif dilakukan untuk menentukan apakah keluhan yang 
berisi informasi jika ditindaklanjuti sebelumnya, bisa mencegah Insiden keselamatan pasien berikutnya. Dari data total 52 pengaduan dan 16 Insiden keselamatan pasien yang dimasukkan, tidak ada korelasi antara lokasi Insiden keselamatan pasien dan keluhan. Keluhan umum difokuskan pada sikap staf, masalah diagnostik dan pengobatan yang tertunda. Insiden keselamatan pasien paling sering muncul dari kegagalan untuk mengenali kerusakan pasien dan meningkat tepat atau tidak benar identifikasi pasien. Keluhan yang diterima terima rumah sakit dari pasien dan keluarga mereka memiliki potensi untuk memberikan suatu bentuk sistem peringatan dini dan jika ditindaklanjuti dapat mencegah insiden keselamatan pasien yang lebih serius. Jadi tindak lanjut diperlukan untuk mengidentifikasi keluhan yang mungkin memprediksi insiden di masa yang akan datang . (Kroening, Kerr, Bruce, \& Yardley, 2015)

Berbagai alasan diungkapkan untuk tidak melaporkan insiden keselamatan pasien, hal ini ditunjukkan dalam penelitian yang dilakukan oleh Marius Brostrom Kousgaard, dkk (2012) yang bertujuan untuk mengeksplorasi alasan untuk tidak melaporkan insiden keselamatan pasien dalam praktek umum, dengan melakukan wawancara kualitatif dengan 12 dokter umum di Klinik praktek umum di Wilayah Utara Jutland di Denmark. Penelitian menunjukkan bahwa sebagian besar responden yang awalnya positif terhadap gagasan pelaporan dan belajar dari insiden keselamatan pasien, mereka benar-benar melaporkan sangat sedikit insiden. Alasan utama untuk tingkat pelaporan rendah karena kurangnya kegunaan praktis, masalah waktu dan usaha di klinik sibuk dengan prioritas yang bersaing, dan pertimbangan kesesuaian dalam kaitannya dengan profesional lainnya. Jadi pelaporan formal, komprehensif, dan sistematis insiden keselamatan pasien akan cukup sulit untuk diwujudkan dalam praktek umum (Kousgaard, Joensen, \& Thorsen, 2012)

Kurangnya pelaporan tentang insiden keselamatan pasien dapat juga disebabkan karena praktisi sering mengalami masalah keamanan yang mereka sendiri bisa menyelesaikan masalah tersebut. Dalam penelitan Hewitt dan Chreim (2015) muncul pertanyaan yaitu Apakah ketika menghadapi masalah seperti itu, yang dilakukan praktisi adalah memperbaikinya pada saat itu dan melupakannya, atau mereka memperbaikinya disaat ini dan melaporkannya? Peneliti mempertimbangkan faktor-faktor yang mendasari dua pendekatan tersebut, dengan menggunakan studi kualitatif dengan melakukan wawancara mendalam dengan 40 praktisi kesehatan di sebuah rumah sakit di Ontario, Kanada. Hasil penelitian menunjukkan 
'memperbaiki dan melupakan' adalah pilihan utama yang paling sering dilakukan praktisi dalam situasi di mana mereka menghadapi masalah yang mereka sendiri bisa menyelesaikan. Situasi ini termasuk (a) penanganan nyaris cedera, yang dipandang sebagai tidak layak pelaporan karena mereka tidak mengakibatkan cedera yang sebenarnya kepada pasien, (b) memprioritaskan pemecahan masalah keselamatan pasien individu,yang dipandang sebagai peristiwa unik atau satu- waktu. Peneliti menyimpulkan bahwa umumnya penyedia layanan kesehatan tidak memprioritaskan pelaporan jika masalah keamanan adalah tetap. Peneliti berpendapat bahwa memperbaiki dan melupakan masalah keselamatan pasien yang dihadapi mungkin tidak melayani keselamatan pasien serta memperbaiki dan melaporkan. Pendekatan yang terakhir "memperbaiki dan melaporkan" lebih tepat untuk keselamatan pasien sebagai upaya preventif (Hewitt \& Chreim, 2015)

\section{c. Pelaporan Insiden Keselamatan Pasien meningkatkan Kualitas dan Keselamatan Pasien}

Kesalahan saat ini. kejadian sistem laporan tidak menyediakan cakupan yang cukup dan memadai sebaga faktor yang berkontribusi terhadap gangguan keamanan dan perawatan yang berkualitas. Penelitian yang dilakukan Morag dkk (2012) yang bertujuan untuk mengembangkan sistem pelaporan untuk mengumpulkan laporan masalah untuk membangun database untuk memandu kegiatan untuk meningkatkan kualitas pelayanan kesehatan dan keselamatan pasien. Sebuah sistem pelaporan masalah dikembangkan untuk digunakan oleh dokter rumah dan diuji di 4 bangsal dari 2 rumah sakit di Israel. Sistem ini didasarkan pada format laporan masalah yang disampaikan oleh dokter dan perawat tentang kesulitan dan bahaya yang mereka hadapi dalam pekerjaan sehari-hari mereka. Laporan dikelompokkan dan dievaluasi oleh tim. Hasilnya, sebanyak 359 laporan dikumpulkan di bangsal selama 12 minggu, dibandingkan. Masalah yang dilaporkan terkait langsung dengan faktor umum yang mempengaruhi kualitas pelayanan dan keselamatan pasien. Dari hasil tersebut, keandalan sistem pelaporan dapat menunjukkan dengan tepat masalah utama per unit yang diselidiki sesuai dengan karakteristik yang spesifik. Jenis sistem pelaporan dapat mengisi kesenjangan informasi penting dengan potensi untuk menjadi sumber database awal untuk meningkatkan kualitas pelayanan, mengurangi kesalahan, dan meningkatkan keselamatan pasien (Morag, Gopher, Spillinger, \& Shpak, 2012)

Penelitian terkait juga dilakukan oleh Kagan \& Barnoy (2013) dengan tujuan untuk menyelidiki hubungan antara budaya pasien keselamatan dengan kejadian dan tingkat 
pelaporan kesalahan medis oleh perawat Israel. Penelitian ini menggunakan kuesioner terstruktur yang dibagikan kepada 247 perawat terdaftar terdaftar dalam program pelatihan di Tel Aviv University. Kuesioner terdiri dari tiga bagian yaitu kejadian kesalahan obat dalam praktek klinis, tingkat pelaporan untuk kesalahan ini, dan pandangan peserta dan persepsi budaya keselamatan di tempat kerja mereka pada tiga tingkatan (organisasi, departemen, dan kinerja individu). Hasil penelitian menunjukkan bahwa kebanyakan perawat mengalami kesalahan medis dari setiap hari untuk setiap minggu. $6 \%$ dari sampel tidak pernah melaporkan kesalahan mereka sendiri, sementara setengah melaporkan kesalahan mereka sendiri "jarang atau kadang- kadang".Tingkat budaya keselamatan pasien adalah positif dan signifikan berkorelasi dengan tingkat pelaporan kesalahan. Budaya keselamatan Pasien, tempat lahir, kejadian error, dan tidak memiliki gelar keperawatan akademis merupakan prediktor signifikan dari pelaporan kesalahan. Penelitian ini menegaskan pengaruh iklim keselamatan untuk kesiapan melaporkan kesalahan. Eksekutif kesehatan dan manajer dapat membuat dampak besar pada pengembangan budaya keselamatan dengan menciptakan dan mempromosikan visi dan strategi untuk kualitas dan keselamatan dengan membina motivasi karyawan mereka untuk melaksanakan program peningkatan di tingkat departemen dan individu. Budaya keselamatan dapat mendorong pelaporan kesalahan oleh staf untuk meningkatkan keselamatan pasien.(Kagan \& Barnoy, 2013)

\section{PENUTUP}

Kesimpulan

Dari berbagai artikel penelitian yang dalam pembahasan maka dapat disimpukan bahwa budaya keselamatan pasien sangat terkait dengan kejadian insiden keselamatan pasien. Dengan meningkatnya budaya keselamatan pasien maka angka kejadian insiden keselamatan pasien dapat diminimalkan. Salah satu upaya yang dapat dilakukan untuk meningkatkan penerapan budaya keselamatan pasien untuk meminimalkan insiden keselamatan pasien adalah dengan melakukan pelaporan insiden keselamatan pasien, baik KNC, KPC, KTC apalagi KTD. Namun, masih banyak praktisi keperawatan yang mengabaiakan pelaporan insiden karena menganggap insiden tersebut masih bisa ditangani dengan sendirinya atau mereka tidak melaporkan jika tidak terjadi cedera pada pasien dan hanya melaporkan jika sudah terjadi cedera. Oleh karena itu, kesadaran tentang budaya keselamatan pasien masih perlu ditingkatkan. Salah satunya dengan 
memberikan pelatihan-pelatihan dan mengupdate pengetahuan tentang keselamatan pasien. Selain itu, motivasi untuk melaporkan jika ada insiden keselamatan pasien juga perlu ditingkatkan, karena laporan dapat menjadi penaganan dini terhadap insiden keselamatan pasien di masa yang akan dating serta mencegah insiden yang sama untuk terjadi kembali,

\section{DAFTAR PUSTAKA}

Agustina Dewi. (2018). Safety Culture Assessment: a Tool for Improving Patient Safety in Hospital . Jurnal Medicoeticolegal dan Manajemen Rumah Sakit,7(2),127-135.

Ahid Ahmad Mudayana. (2014). Peran Aspek Etika Tenaga Medis Dalam Penerapan Budaya Keselamatan Pasien Di Rumah Sakit. Jurnal fakultas kedokteran universitas Andalas, 37(1), 6974.

Buhari Basok . (2019). Budaya Keselamatan Pasien Rumah Sakit Pemerintah Dan Rumah Sakit Swasta Di Kota Jambi. Jurnal Aisyiyah Medika, 3(1),1-18.

Hawkins, C. T., \& Flynn, L. (2015). Patient Safety Culture and Nurse-Reported Adverse Events in Outpatient Hemodialysis Units. Research and Theory for Nursing Practice: An International Journal, 53-65.

Herawati Yennike Tri. (2015) Budaya Keselamatan Pasien di Ruang Rawat Inap Rumah Sakit X Kabupaten Jember. Jurnal IKESMA, 11(1),52-60.

Iriviranty Afrisya. (2015). Analisis Budaya Organisasi dan Budaya Keselamatan Pasien Sebagai Langkah Pengembangan Keselamatan Pasien di RSIA Budi Kemuliaan Tahun 2014. Jurnal Administrasi Rumah Sakit, 1(3), 196-206.

Najihah. (2018). Budaya Keselamatan Pasien dan Insiden Keselamatan Pasien Di Rumah Sakit. Jurnal Of Islamic Nursing, 3(1), 1-8.

Nurumal Mohd Said, Najwatul Madihah Sabran, Siti Hazariah Abdul Hamid, Muhammad Kamil Che Hasan. (2020). Kesadaran Perawat Terhadap Budaya Keselamatan Pasien Baru Rumah Sakit Universitas Yang Didirikan. Jurnal fakultas Keperawatan Indonesia 23(2), 119-127. 
Simamora, R. H. (2018). Buku ajar keselamatan pasien melalui timbang terima pasien berbasis komunikasi efektif: SBAR. Medan: USUpress.

Simamora, R. H. (2020). Learning of Patient Identification in Patient Safety Programs Through Clinical Preceptor Models. Medico Legal Update, 20(3), 553-556

Tetuan Theresa. (2017). Does Systems Thinking Improve the Perception of Safety Culture and Patient Safety. Journal of Nursing Regulation, 8(2), 31-39.

Yasmi Yulia , Hasbullah Thabrany. (2018). Faktor-Faktor yang Berhubungan dengan Budaya Keselamatan Pasien di Rumah Sakit Karya Bhakti Pratiwi Bogor Tahun 2015. Jurnal Administrasi Rumah Sakit, 4(2), 98-109. 